indicate this possibility. And although he professes a piety more than conventional, no sacred name but "Dios" occurs in the book, except as required by the narrative.

In one passage, in chapter vi of the "Voyage," he refers to "the relation that I have made of the religious customs of the African races "; apparently a lost treatise.

Altogether the man himself, his personal narrative, and the extracts from Thurán Shah, seem to deserve some notice, and make me desire further information. A translation with a few notes (omitting the Persian History) would make about as big a book as the Hakluyt Society's first volume of Azurara's "Conquest of Guinea." 1

W. F. Sinclair (late I.C.S.).

\title{
3. The Communal Origin of Indian Land Tenures.
}

DEAR SIR,-As an accurate knowledge of ancient and modern systems of land tenure in India is of such great value to all Oriental students, I trust you will allow me to record in the Journal of the Royal Asiatic Society a few remarks on Mr. B. H. Baden-Powell's valuable and comprehensive account of the Indian village as given in his large work on "The Indian Village Community" and in his "Study of the Dakhan Villages" published in the R.A.S. Journal for April, 1897. His book, while generally accurate and complete as to Bhaiāchāra and Pattidari villages, is unfortunately, as I shall now try to show, entirely wrong in denying ( 1 ) the existence of any custom of holding the lands of ryotwäri villages in common, ${ }^{2}$ and (2) the existence of any trace of a claim to property in waste land until the soil was cleared and prepared for cultivation. ${ }^{3}$

1 In the numerous digressions scattered through the histarical part of the book, casual mention is often made of Teixeira's earlier travels. We gather that in 1588 he sailed from Ceylon to Goa. He seems to have been in Persia by 1595 at latest, and only left it in 1597 , when he sailed to Goa, and thence to Malacca.

2 "The Indian Village Community," chap. i, sect. ii : "The Ryotwāri Village,' p. 9.

3 "Study of the Dakhan Villages," J.R.A.S., April, 1897, p. 243. "Indian Village Community," chap. v, sect. iii : 'Aryan Idea of Property in Land, pp. 202-6. 
The author himself admits that the ryotuãri village system is derived from the Southern Dravidian village and the Parha, or forest-clad clan territory, in which these villages were founded, and that it is to this form of village that very much the largest number of villages belongs. ${ }^{1}$ He rightly attributes the primary origin of organized society to the aggregation of tribes, but he seems to hold that the existence of a headman or chief was a necessary part of the primary village organism, though it is not, as Sir H. S. Maine has remarked, originally a feature of tribal constitution. ${ }^{2}$ I myself have seen a great deal of both tribal and village formation in Central India and Western Bengal, and judging from my own experience among the nomad noncultivating forest tribes, those which change their cultivating settlements every two or three years and the migratory cultivators who wander from village to village in the less settled parts of the country, it seems to me impossible to believe that the first villages were founded under the guidance of a recognized permanent chief of a group of cultivators supposed to be united to one another by ties of kindred. If we take the customs of the present forest tribes as a guide to those of the past, we must believe that the original group from which the southern tribe was formed was one in which the nucleus was a family of hunters, in which the cohesive home element was supplied by the mother and her children. These children's father or fathers were always more or less inconstant members of the group, for they might always begin to form another if they found male comrades who could give them more efficient aid in their hunting pursuits than they could get from their own families. Hence it was that the matriarchal constitution of society in India arose from a group of mothers with their children, who grew up together from their birth, and thus formed an alliance which, beginning in childhood, lasted all their lives. Such a central group

1 "The Indian Village Community," chap. iv, sect. iii : "The Dravidian Group,'p. 160; chap. vi : 'The Tribe and the Village,' pp. 230-2.

2 "The Indian Village Community," chap. i, pp. 9-10. 
of capable mothers, sisters, and brothers united together would be sure to attract candidates for admission into their ranks, who, if on trial they proved to be useful additions, would, though originally of alien birth, become permanent members of it. Hence was formed the population of the original permanent village, in which the men were all looked on as brothers of the women. The affairs of the children were managed, as they still are in many Indian castes, by these maternal uncles, the fathers being always the men of an adjoining village belonging to the same Parha, who had to look after the children of their own village. It is upon a similar but somewhat more fluctuating basis that the customs of the present nomad forest tribes are founded, who are quite ready to receive any wandering recruits they pick up when they have once made up their minds as to their capabilities; this readiness to receive unrelated members who will benefit the tribe survives in the caste institutions of the Tantis, Doms, Dosadhs, Chasas, Chandels, Bagdis, and numerous other castes, including the high-born Rajputs, very many families belonging to this last caste being notoriously known to be of alien blood.

All the nomad forest people make hunting, in the form of trapping and snaring game, one of their principal pursuits; and the men spend most of their time in finding out where animals most abound, learning their baunts thoroughly and then killing them, and also in searching for edible plants and roots. It was probably among the women that the idea first arose of growing food, which could be made available when the forest supplies failed. This priority of the women as the first cultivators of the soil is acknowledged in the imitative seasonal dances of the Mundas, for in the figure representing the sowing of the seed and the preparation of the ground all the work is done by women.

Of course these groups had leaders, like all other coherent societies, but their power was permanent only if they were able to make the other members believe in the advantage 
arising from their rule; and the permanency of the tenure of the leader was only secured when in the struggle for existence some tribe under a succession of distinguished chiefs so far established its superiority as to be able to appropriate to itself a hunting tract sufficiently large for its wants when the supplies of wild animals, fruits, and roots were eked out by harvested crops. It was from these territories, which became the Parhas or clan properties into which India was divided by its earliest occupants, that the idea of landed property first arose. But this property was entirely communal and belonged to the united tribe, and no part of it was owned by any individual. In these early days the chief necessity felt by any group was the want of members, especially of those who were able by their intelligence and activity to add to the resources of the community. Hence, when a society of capable and efficient food-providers had either been formed or was in process of formation, it must have been a chief object of the leaders to prevent any split or secession, and also to encourage the idea that all work must be done for the public benefit. Among the tribes who first founded permanent villages this anxiety for the promotion of communal prosperity showed itself in their careful attention to the education of the young, who were looked on, except during their earliest years, when they wanted a mother's care, as the children of the village, and this is the status they hold in the Nagga and Ooraon villages. These children were carefully trained by the elders in all the practical knowledge they possessed, and it was this national system of instruction that gave birth to the village schools called Patshalas, universally found among all agricultural communities in Central India. But in this system of teaching, individuals were not allowed to assert themselves, and all were taught to think that their first duty was to obey their teachers and leaders, and to work for the prosperity of the village. If in after-life any of these trained children, or other members of the community, took an independent line, in opposition to the ruling powers of the village and parha, 
their fault, unless promptly repented of and atoned for, met with but short shrift, for only flight could save the rebels from death. It was in this system of social despotism that the character of the Indian Dravidians was moulded, and from it they emerged as a most obedient and law-abiding race, always ready to submit to constituted authorities. But with this there was mingled an intense hatred of innovations, and a spirit of dogged obstinacy engendered by their long struggle for the establishment of their social superiority to neighbouring tribes, and the acquisition of the ability to rule large territories. This combined spirit of obedience and of obstinate resistance to whatever was displeasing to these born conservatives, when infused into the mental fibre of the many intercrossed races born from the union of the Dravidians with the numerous later immigrants who succeeded them in India, has produced diversities of character most interesting to ethnologists, but most perplexing to those who have to govern them.

The system of land administration which grew up under the despotic rule of the socialistic Dravidians was very different from that to which Mr. Baden-Powell ascribes the formation of Indian villages. For in these South Indian communities the claim of any individual to a right of property in land he had cleared would have been regarded as rank rebellion, and hence it was utterly impossible that in these original ryotwa $r i$ villages the several portions of the village could be, as he asserts they were, "allotted and taken up severally, and enjoyed independently from the first." 1

In the original village, while the property in the soil was vested in the collective owners of the Parha, its produce was the property of the village community. It was used to supply food to them at their common meals, a custom still retained in the Ooraon villages, where all the village young men eat together, and it was this custom which emigrated to Europe with the other constituent customs of the Indian village-such as the annual partitions of land, the reverence p. 9.

1 “"The Indian Village Community," chap. i, sect. ii : “The Ryotwãri Village,' 
for the village grove, and the boundary snake encircling the village limits-and gave rise to the common meals of all the Dorian races. From this point of view, as Mr. C. W. Benett, Settlement Officer of Gonda, in Oude, says, in a passage quoted by Mr. Baden-Powell- “The produce was the common property of every class in the agricultural community, from the Raja to the slave. No one is absolute owner any more than the others, and the basis of the whole society is the grain heap." 1 In the communal villages of the earliest type, under a Munda or headman, which divided among themselves the soil of the Parha under the head Munda or Manki, it was a matter of complete indifference who should be the cultivator of any particular plot. What the community had to do was to cultivate all the cleared land, and the village elders were the taskmasters, whose duty it was to see that this was done. Villages provided with a nucleus of able supervisors soon began to increase in size and to branch out into hamlets in the immediate neighbourhood, tilled by emigrant colonists of the parent village. It was this latter which became the capital of the Parha, peopled by its offshoots, and it was the Munda of this village which became the Manki of the Parha. Hence all governments in India grew to be expansions of the primaeval village. The centre point was the original village grove; this was the centre of the central village of the Parha, and when Parhas grew into kingdoms, the king's province was the centre of those ruled by his vassal chiefs, and in the Sanskrit distribution of Indian geography, Jambu-dwipa, the province of Central India, became the centre of the seven provinces into which India was divided, and it was thence that the king of the Kuru-Panchālas is said to have ruled the country. When the original communal organization of the village was changed by the coming of northern immigrants, who brought with them the custom of marriage and the division of the community into families, the soil began to be divided upon a family basis, and the

1 "The Indian Villag $\theta$ Community," chap. v, sect. iii : "Aryan Ideas of Property in Land,' pp. 212-3. 
villages to be organized in the form found in the old Gond kingdom of Chuttisgurh, the land of the thirty-six forts or drūgs, a Madras term still used in Chuttisgurh. There the villages in the thickly populated parts of the country are all divided from one another by definite boundaries well known to and carefully guarded by the Gorait, or village priest of Goraya, the boundary god, the guardian snake which encircles the village, of which the boundary line is called "the sacred snake." In each village not only cultivated, but also waste, land is included. The cultivated lands are all divided into a certain number of lots called Koonts or Lakas, generally five in number. One of these belongs to the headman, and the remainder are ruled by chosen elders, whose duty it is to assist the headman in dividing all the arable rice land of the village into fields. These are so arranged that every cultivator shall receive as his share, at the periodical distribution of village land, a proportion of every kind of soil sown with rice exactly equivalent to the share due to his total holding. The whole area of the village rice land is calculated, with wonderful accuracy, according to the number of measures of seed required to sow it, and these are subdivided into the number of measures which will sow each koont. It is the duty of the koontdar to apportion the fields of his koont to the number of cultivators allotted to him, and their several capacities, these being, since ploughing was instituted, calculated according to the number of plough bullocks each cultivator possesses. The prevalence of this custom at the time of the first settlement of Chuttisgurh, from 1863-9, is proved by the following extracts from the Settlement Report of Mr. Chisholm, Settlement Officer of Belaspore, the northern part of Chuttisgurh, and from my Report as Settlement Officer of the southern districts.

Mr. Chisholm says (para. 147) :-_"Another peculiarity is the practice of changing fields. This would occur periodically, so that no tenant should monopolise the best land. This practice is not universal; it exists in some villages only. The want of attachment, however, to individual holdings 
is an almost universal feature, and a very trifle will often induce even a hereditary ryot to relinquish his land."

I say (para. 171):-"It is the custom, when a new ryot comes to a village, always to give him a portion of oultivated land proportionate to the number of plough bullocks he has; and if some other ryot does not opportunely vacate his holding, so as to allow the new-comer to step in, the land required is usually obtained by throwing the whole of the village land into one lot, and redistributing it." I did not, however, in my printed report, speak of what was well known to me from four years' constant intercourse with the ryots, the original existence of a custom of redividing the land every five years, which was substituted for the still earlier one of annual divisions of the land. This last is that mentioned in Mr. Place's Report of the Vellālar villages in the Chingleput district of Madras, quoted by Mr. Baden-Powell," where he says: "The council, that is the panchayut, determined each year what portion of land each group should undertake, and the village body worked without any separate or permanent allotment of lands." This custom of dividing the lands had been in Chuttisgurh generally followed by most of the villages, except those situated in the most fertile parts of the district, where the soil was generally of a uniform quality, and which were peopled by Kurmis, Telis, and other similar castes of good farmers. In these the ryot generally held the same lands from year to year without any change. But in every village the divisions into koonts always existed, and this shows that the whole constitution of the village in which one koont was allotted to the headman, rests on the original custom of annual redistributions of the land, for it is the heads of the village koonts, including the headman, who form the village Panchayut. Their primary official duties as assistants to the headman were to superintend the division of the land and its subsequent cultivation, so that the productive power of the village might not suffer

1 "The Indian Village Community," chap. ix, sect. i : 'Ancient Joint Villages in Madras,' p. 375. 
from the idleness of the cultivators. That the Panchayut, with the accompanying system of shifting tenures, which was the original cause of its appointment, was an original feature in village institutions throughout India, is proved by Mr. Baden-Powell, in the passages where he says, "the Panchayut was once the special feature of the constitution of the joint village," 1 and in his quotation from $\mathrm{Mr}$. Whiteway, who says that "the panchayut is a Bhaiāehāra institution," existing in the Jât villages in Mathura "in full perfection." The shifting tenures, with the accompanying periodical redistributions of land, existed until a very recent period in Madras, as well as Chuttisgurh, for Mr. J. Thomson, Resident of Travancore, has told me that he remembers the custom as existing in South Arcot, when he was employed in that district, and it used also to take place in some of the Ooraon villages of Chutia Nagpore.

Hence it is clear that the custom of the communal holding of land, with periodical redistributions of the fields, is one that is inherent in the constitution of all villages founded by the southern rice-growing tribes. And that it was taken by them to Northern India is proved, not only by the universal existence of traces of Panchayut rule, but also by its actual existence in Kangra, ${ }^{3}$ and by the custom in the Gūmal Valley of the Dera Ismail Khan district of cultivating in common the rice lands sown with the autumn crop. ${ }^{4}$

It will be universally found throughout India that in all Dravidian and Kolarian villages, and even in those founded by later Northern immigrants on foundations laid by their indigenous predecessors, land is not looked on as in any sense the individual and hereditary property of the cultivator. And every ryot of all ryotwäri villages will,

1 "The Indian Village Community," chap. $x$ : "General Summary and Conclusion,'p. 441 .

2 "The Indian Village Community,", chap. vi: 'The Tribe and the Village,' p. 283 .

3 "The Indian Village Community," chap. iv: "Customs regarding Landholding observed among the Non-Aryan Races,' p. 132.

" "The Indian Village Community," chap. vi: "The Tribe and the Village,' p. 261. 
except in those villages where, primitive institutions have been entirely obliterated by the last immigrant invaders, whom it is the custom to call Aryans, acknowledge that his equitable rights in the village were not rights to any special plots of land, but to whatever fields the communal panchayut would give him, that these might be taken from him when the fields were required by the community, and that he himself might be ousted by them from the village. Upon these terms each ryot admitted as a member of the community possessed hereditary rights, and his descendants can always, in parts of the country where aboriginal customs prevail, get an allotment of land in his ancestral village when returning to it after a number of generations. But this land is given from the cultivated area by the community just as the klêros or holding of each Greek tenant was given him, not by his parents, but by the Phratria on his coming of age, and the five erws of land, the hereditary right of each Cymry, was given to him by the tribe on the same occasion. These allowances were given from the arable area, and the holdings of previous occupiers had to be adjusted to allow of the gift. Both the Greeks and the Cymry, like the communal villagers of Europe, brought their village customs from India, where the first villages were founded.

It is when we turn from the original village customs founded by the rice-growing races of the South to the tenures of the barley-growing tribes of the North-West that we find those ideas of individual and family proprietary rights in definite portions of land which were utterly unknown to the earliest makers of villages. These people are all immigrants from the North, who grow as their principal crops millets, oil-seeds, wheat, and barley, which have all been imported into India from Mesopotamia and Asia Minor. They first introduced into India the custom of marriage, and made the sign of the marriage bond, the Sindur-dan or red mark drawn by the bridegroom down the parting of the bride's hair, to signify that the pair are united in blood-brotherhood, the actual interchange of blood being added in many castes. 
These immigrant tribes based their land customs chiefly upon those inherited from one of the numerous stocks from which the ploughing races, the original meaning of the word Aryan, are descended. These were the Gothic sons of the totem bull and cow, the pastoral tribes of North-West Europe, the Bauers of North Germany. Among these people the communal land tenures which' generally prevail throughout the rest of Europe, South-Western Asia, and India, never existed. With them the land held and tilled by each cattle-owning family was the family property, defended against all comers, and they did not live in contiguous huts like those of the communal villagers, but the whole family lived together in their own homestead. Their farms and grazing grounds each included in its ring fence were all grouped round those of the Hauptmann of the Bauerschaft, where there was the central fort for common defence, the peel tower of English border lands and the meeting hall of the allied farmers, the Sabha of the Vedic age. These were the people who came down into India as the Jäts and Cheroos, and changed the original provinces or Parhas of united villages, founded by the mountain Mundas from the NorthEast and the Dravidians or sons of the tree, into Drügs or forts. It was they who divided the lands they occupied into family properties by the institution of Bhaiāchāra and Pattidari villages in territories they found to be imperfectly cleared.

An excellent instance of the change produced by the coming of one of the first immigrant tribes from the NorthWest is given by the customs of the Kandhs, whose tenures are cited by $\mathrm{Mr}$. Baden-Powell as proving the original existence throughout India of indigenous family proprietary rights to the soil. These warrior Kandhs, who worship the sword, are undoubtedly very early immigrants, for in their marriage ceremonies the binding tie between the married couple is not the making of blood-brotherhood, but the exclusion of both bride and bridegroom from his clan by the father of the bride, who spits upon both their 
hands. The union of the two is effected at their betrotbal by ceremonies which betoken a descent from agricultural ancestors and not from warrior progenitors, who brought in later the worship of the sword and introduced throughout India the custom of mingling blood. At the Kandh betrothal the bridegroom puts a necklace on the bride, and she pours oil over him, and this last ceremony shows that it is imported, with the reverence for oil, from Asia Minor. It is in the rules controlling these marriages that we find certain proof that the Kandh political system arose from an alliance of Northern agriculturists with Dravidian farmers. In the first place the marriages are all exogamous according to the Indian rule, and not endogamous in the family according to Northern custom. The incoming immigrants, when settled in the country, formed the whole of the Kandh territory into one parha, which they divided into fifty gochis, each bearing the name of a muta or mother village. Each gochi was supposed to represent the property of a family. These gochis, as families, were subdivided into sub-septs called klambus, which are purely family divisions. No man can marry any girl belonging to his own gochi or klambu. But the rule as to the gochi is the more imperative of the two, for a man may not marry a girl, though she belongs to a different klambu, if she lives in his own gochi. The whole system is evidently one of compromise, framed by a tribe of Northern descent, who traced their genealogy on the father's side (as is the rule in the gochis and klambus) when they united themselves with semi-aboriginal matriarchal tribes who traced their descent through the mother. These latter, like the Binds and Gonrhis still living in the same country, forbade marriage between a man and woman of the same village. This custom, again, is an outcome of the still older matriarchal rules of which vestiges are still found among the Kols and the Juangs. Under this custom all village children were begotten at the seasonal feasts held in the Akra or dancing ground under the shade of the village grove, and hence they were all children of the village 
parent tree. From this arose the custom, observed by almost all the agricultural castes in Bengal, of marrying every bride of the caste, and sometimes her husband also, to the parent tree before the marriage binding the couple together. The original form assumed by the custom is shown in the rule observed by the Juangs, Ho Kols, and the widespread tribe of the Bhuiyas, which forbids the men and girls of the village to dance together, but prescribes that the girls shall always invite the men of neighbouring villages to their dances. It is in accordance with this rule that among the Ho Kols the girls of one village, accompanied by the young men of another, often go from village to village for weeks together at the great Mägh festival in January-February, being entertained by and dancing together at each village they come to. This rule was made by the original Dravidian village makers as a means of binding all the villages of a parha in perpetual alliance, and under it every man could become the father of the children of any woman in the parha, except the women of his own village; and he was not allowed to live with the mother of his children, but must help to superintend the education of the children born in the village where he lived with his tribal sisters.

Under the rule of the invading Northerners, who reckoned descent by the father's side, and who married the Southern daughters of the land they had conquered, the old communal tenure of the matriarchal Dravidians, who only knew their mothers, was altered into the territorial tenures with definite boundaries, now held by the Kandh cultivators. But even in these villages I think it would be likely that a careful survey of the village would disclose very distinct traces of the old communal holding. As an instance, I may refer to my own experience in Chuttisgurh, where in villages in which the tenure had remained unchanged for many years, the evidence of the old custom of distributing the lands on the principle of giving each cultivator his due share of each kind of soil in the village was unmistakably marked by the very small size of many 
of the felds and the scattered nature of the tenures. For even where only a small area of a particular kind of soil was to be found in the village, it had to be cut up into plots corresponding with the number of the villagers. These plots were often so small that they could not be shown on the field maps of the rice lands until the scale was altered from thirty-two inches to sixty-four inches to the mile. In order to carry out this rule, each ryot's holding and the area belonging to each koont were scattered all over the village, thus obliging cultivators in large villages to go from one to two or three miles to visit and till each plot of their holdings. Such a distribution of the fields could never have existed if each tenant were thought to have a right to the land he or his ancestors had cleared; in that case every holding would have been in a ring fence.

In conclusion, I think I may safely say that everywhere throughout the length and breadth of India it will be found that the Dravidian matriarchal cultivator, who has introduced his distinctive cerebral letters into Sanskrit and Pushto, and has left very distinct traces of his speech in all Prakrit and Pali dialects, has also left the mark of his inborn conservatism upon the agricultural tenures and customs. That everywhere the oldest village system was the communal tenure of the Dravidian sons of the tree, whose staple crop was rice; and that the rule of individual property in land, which distinguishes the Bhaiāchāra and Pattidari systems of tenure, and which has in many places all but obliterated the old communal rules in ryotuari villages, is a later importation into India made by the barley-growing immigrants from Asia Minor.

J. F. HewitT.

\section{DIMĀPŪR.}

Dear Sir,-I think it is a great pity that one at least of the photos of the Y-shaped stones described by Dr. Brown was not given in the last number, and hope the 